\title{
The variability of population and individual traits of medicinal plant Valeriana officinalis $L$. var. officinalis Mikan under different site conditions
}

\author{
KINGA KOSTRAKIEWICZ-GIERAŁT \\ Department of Plant Ecology, Institute of Botany, \\ Jagiellonian University, Gronostajowa 3 \\ 30-387 Kraków, Poland

\section{Correspondence:} \\ Kinga Kostrakiewicz-Gierałt \\ e-mail: kinga.kostrakiewicz@uj.edu.pl
}

Key words: clonal growth; generative reproduction; genet, population; useful plant

\begin{abstract}
Purpose: The purpose of investigations was to evaluate the effect of floristic composition, soil moisture and $p H$ on the variability of traits of Valeriana officinalis $L$. var. officinalis.

Materials and methods: The studies were carried out in the years 2014 2016 in two study areas consisting of patches of community dominated by Filipendula ulmaria with a substantial share of low-and medium-growing perennials (Patch I), tall-growing perennials (Patch II), as well as tallgrowing perennials and shrubs (Patch III).

Results: Similar tendencies were observed in both study areas. The plant and cryptogam cover showed neither spatial nor temporal variability, while the height of neighbouring plants, as well as the $p H$ and moisture of soil, augmented in subsequent patches. The lowest abundance of subpopulation Valeriana officinalis was noted in Patch III. During the study period seedlings and juveniles were not found in any of the patches, whilst the share of vegetative genets diminished gradually at the cost of generative individuals and ramet clusters. The majority of individual traits (e.g. number of ramets, radical leaves and flowers, number and height of flowering stems) angmented in successive patches, while the number of radical leaves in generative individuals and ramet clusters, as well as the height of flowering stems and number of flowers, additionally angmented in consecutive years.
\end{abstract}

Conclusions: The considerable share of vegetative individuals in sites dominated by low-statured plants contributes to rejuvenation of subpopulations. The clonal growth might protect all subpopulations from regression. The substantial production and dimensions of flowering stems in vicinity of tall-growing perennials enlarges the chances for successful pollination and seed dispersal.

\section{INTRODUCTION}

All cultures from ancient times to the present day have used plants $\mathrm{A}_{\text {as a source of medicines }(1,2) \text {. As reported by Chen et al. (3), more }}$ than one-tenth of plant species are the chief source of active compounds for drugs to cure diseases of man and his livestock. The majority of the population of developing countries depends on traditional remedies in primary health care, while many people from industrialised countries consider traditional medicine as complementary or an alternative to conventional therapy. The increasing demand for herbal drugs and
Received July 14, 2017. Accepted May 14, 2018. 
natural health products throughout the world has contributed to exhausting $20 \%$ of wild resources of medicinal species (4). Another serious cause of the accelerated loss of the natural resources of therapeutic plants is the destruction of their habitats. Such a phenomenon is particularly widespread in Asia, Africa, Latin America and the Middle East, where numerous medicinal plants are threatened primarily due to uncontrolled logging of forests, as well as rapid agricultural and urban development (5). Simultaneously, it should be pointed out that also in Europe, secondary succession and habitat degradation has increased the risk of extinction of numerous therapeutic plants. According to the Anonymous ( $\sigma$ ), the best means of conservation of medicinal species is to ensure their persistence in natural habitats. Furthermore, the role of the conservation in situ also has been emphasised by other authors $(7,8)$, who highlighted that monitoring of populations is neglected and demographic studies are still strongly desirable.

Currently, one of medicinal taxa suffering the progressive loss of populations as a result of habitat degradation is Valeriana officinalis $\mathrm{L}$. To date, the ecological investigations of the aforementioned taxon have focused on studies of the relation among yield quality and: date of sowing (9), planting density $(10,11)$, fertiliser application (12), weed control methods use (13), inoculation of roots with bacteria strains $(14,15)$, planting method $(10)$, and devel- opmental stage (17). As a result of the scarcity of studies conducted in natural localities, the present investigations were carried out, aimed at an evaluation of the impact of habitat conditions on population and individual traits of Valeriana officinalis L. var. offcinalis. The specific aims were to assess the variability of: (i) number of ramets, number of leaves in rosettes and the length of the longest leaf in vegetative and generative individuals and ramet clusters, (ii) number of flowering stems in generative individuals and ramet clusters, (iii) height of the highest flowering stem, (iv) number of flowers per generative stem.

\section{Study species}

Common valerian (syn. Garden heliotrope) Valeriana officinalis L. var. officinalis Mikan considered as synonym of Valeriana officinalis (18) or Valeriana officinalis L. subsp. officinalis (19) is a rhizomatous rosette-forming clonal plant (20). The blade of the long-stalked rosette (basal, radical) leaves is pinnate, lance-shaped and serrate. The cylindrical, furrowed stems reach up to $200 \mathrm{~cm}$ and bear dichasial clusters of sweetly scented pink or white flowers developing on the branches. In Poland flowers bloom from June to August and are frequently visited by many fly species, especially hoverflies of the genus Eristalis. The lanceolate-oblong achenes are wind-dispersed (21). After a successful germination of light-demanding seeds lasting

Table 1. The composition of dominant and subdominant species within permanent study plots established in Patches with considerable share by low-and medium-growing perennials (I), tall-growing perennials (II), as well as tall-growing perennials and shrubs (III) in study areas A and $B$ areas. The Arabic numbers mean the cover-abundance degree visually estimated for particular species according to the Braun-Blanquet scale.

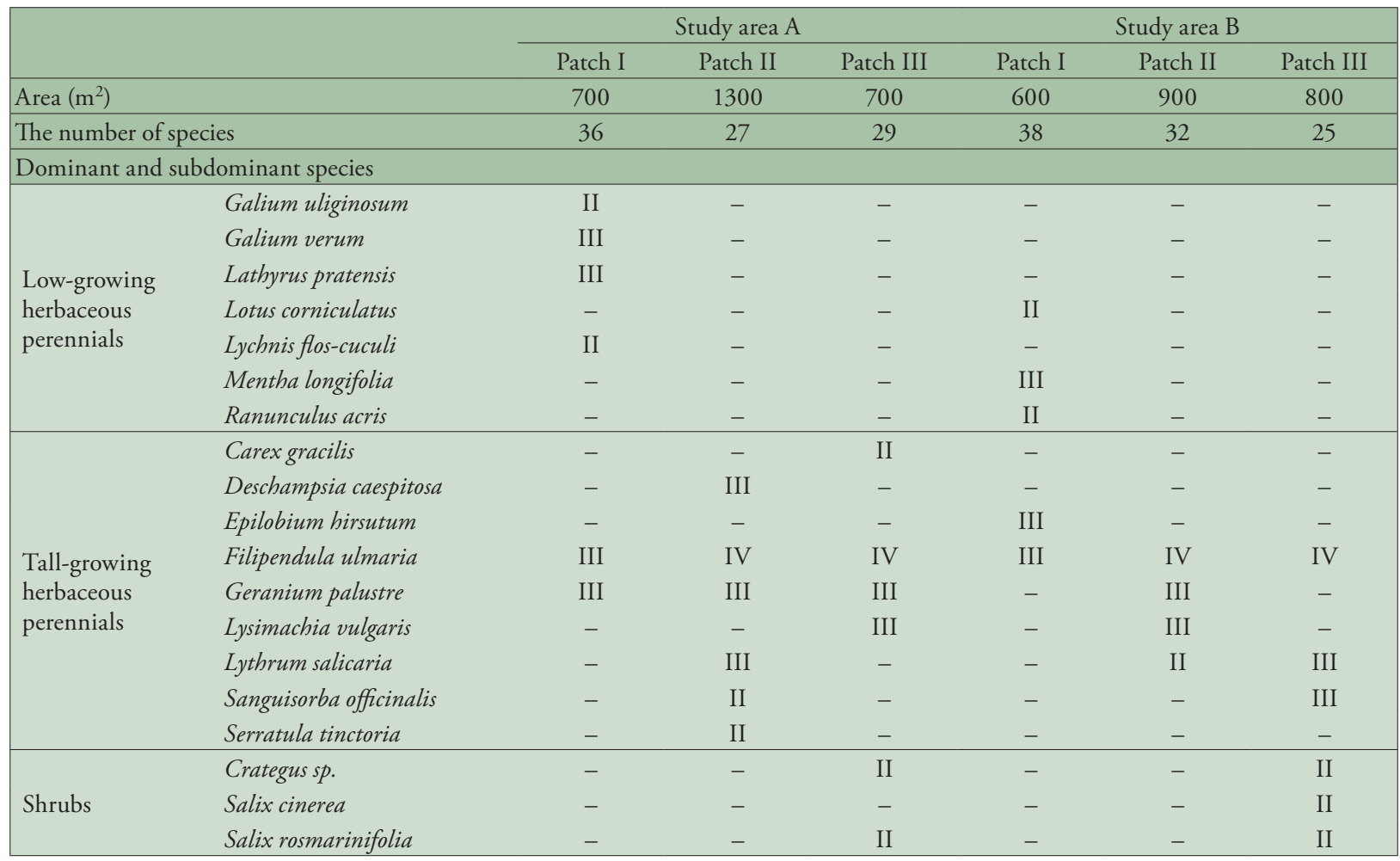


from 10-20 days and occurring usually in spring, the seedling appears (22). The following developmental stage might be distinguished: juvenile (individual with a rosette of non-divided leaves), vegetative (individual with a basal rosette with pinnate leaves), generative (individual with at least one flowering stem created around the second year of growth). Over the following years the rhizome grows and the number of ramets multiplies.

Common valerian represents an Holarctic element, euro-temperate sub-element (23); native to Europe and parts of Asia. Individuals can grow in a variety of different habitats ranging from water banks, through wet meadows and low peat bogs, to moist forests (mainly alder forests). They are also used in the treatment of hypertension and cardiac arrhythmia (24). According to Anonymous (22), the leaves and flowers also contain some of the roots' properties. Common valerian is listed in the European Red List of Medicinal Plants (25), as well as in many national Red Books and Lists (26-29).

\section{Study area}

The investigations were carried out in the south-western part of Krakow (southern Poland) in the Kostrze district (N 50 1'26'; E 19 $\left.50^{\circ} 1^{\prime \prime}\right)$ at ca. $210 \mathrm{~m}$ a.s.l., on the low flood terrace of the Vistula River where the limestone hills (Jurassic-Cretaceous) and tectonic depressions of the Brama Krakowska gate occur. The greatest area is covered by abandoned meadows from alliance Molinion caeruleae Koch 1926. In its vicinity numerous plant communities have formed, from the deciduous forests covering the slopes of the Vistula valley, through the xerothermic calcareous grasslands occurring on limestone and chalk hill slopes, to the ruderal communities appearing near buildings and along the edges of roads (30).

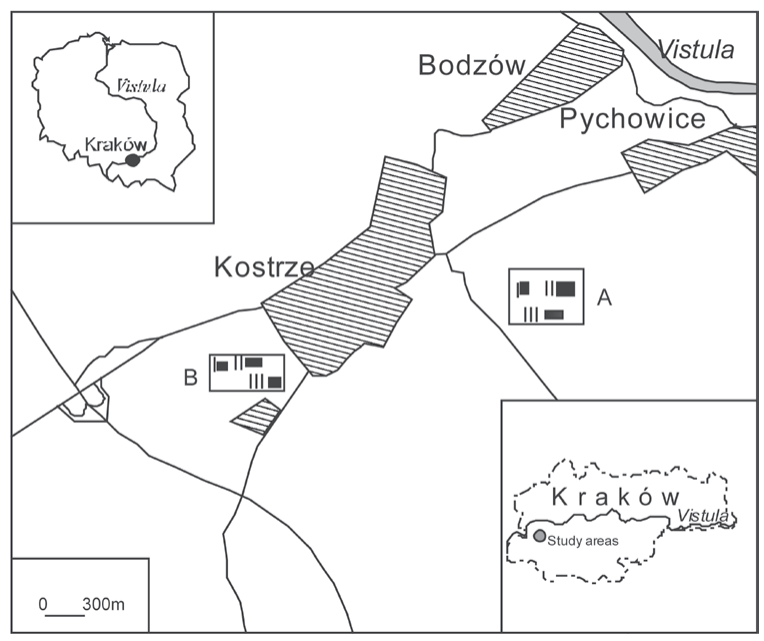

Figure 1. The localities Patches with considerable share low- and medium-growing perennials (I), tall-growing perennials (II), as well as tall-growing perennials and shrubs (III) in study areas A and $B$.
In order to confirm the repeatability of the results, the investigations were conducted in two study areas ca. $2 \mathrm{~km}$ apart (named A and B). Each of them consisted of three neighbouring patches of community dominated by Filipendula ulmaria with considerable share of: low- and medium-growing perennials (Patch I), tall-growing perennials (Patch II) and tall-growing perennials and shrubs (Patch III). The locality of Patches is presented in Figure 1, whilst their detailed characteristics is given in Table 1.

\section{MATERIAL AND METHODS}

\section{Studies of habitat conditions}

In every Patch one representative, permanent study plot $(15 \mathrm{~m} \times 15 \mathrm{~m})$ was established and fenced. In each plot all dominant species (with cover exceeding $25 \%$ of study plot) and subdominant species (with cover ranged from $5 \%$ to $25 \%$ ) were identified, while their cover-abundance degree was visually estimated according to BraunBlanquet approach. Within each plot, 20 measuring points were chosen and marked with plastic pegs. Four points were placed systematically in the corners of the permanent plots, while the remaining points were chosen randomly. The marked points served as centres for setting iron rims, $30 \mathrm{~cm}$ in diameter, used for the evaluation of biotic (plant and cryptogam cover, height of the vascular plants) and abiotic habitat conditions (moisture and $\mathrm{pH}$ of the soil). The plant and cryptogam cover was measured as a percentage of ground surface $(706.5 \mathrm{~cm})$ covered by vascular plants and cryptogams (moss and lichens). The average height of the neighbouring plants was received on the basis of measurements of length (from soil level to the top) of the lowest and highest stems (excluding Valeriana officinalis var. officinalis) growing within the rim, using a folding tape measure. Soil humidity and $\mathrm{pH}$ value was measured using a BIOWIN soil sensor (range 1-10) in the $5 \mathrm{~cm}$ deep upper soil layer. Soil humidity range: 1-3 - dry, 4-7 - moist, 8-10 - wet; pH range: 1-6-acid, $7-10$ - alkaline. The survey of the habitat conditions was performed on 12 July 2014, 8 July 2015 and 10 July 2016.

\section{Studies of population and individual traits}

Considering that Valeriana offcinalis var. officinalis belongs to clonal plants, the terms 'an individual' (genet) and 'ramet cluster' were adopted as the basic demographic units. An individual is a plant originating from a zygote. This term was applied to plants creating a single ramet such as a leaf rosette or generative stem. The ramet cluster was understood as an aggregation of ramets formed in the course of vegetative proliferation of a genet. Therefore, the ramet cluster might be either a genet or a group of independent units emerging as a result of the fragmentation of a genet or several genets. 
Table 2. The mean values (range) of plant and cryptogam cover, height of neighboring plants, soil reaction (pH) and moisture in permanent plots located in Patches with considerable share of low-and medium-growing perennials (I), tall-growing perennials (II), as well as tall-growing perennials and shrubs (III) in study areas $A$ and B in the years 2014-2016. Symbols of the level of statistical significance of values of the Kruskal-Wallis $H$ test: ${ }^{n s}-$ not significant, ${ }^{*}-P \leq 0.05,{ }^{* *}-P<0.01,{ }^{* *}-P<0.001$.

\begin{tabular}{|c|c|c|c|c|c|c|c|c|c|}
\hline & \multirow[b]{2}{*}{ Year } & \multicolumn{4}{|c|}{ Study area A } & \multicolumn{4}{|c|}{ Study area B } \\
\hline & & $\begin{array}{l}\text { Patch } \\
\text { I }\end{array}$ & $\begin{array}{c}\text { Patch } \\
\text { II }\end{array}$ & $\begin{array}{c}\text { Patch } \\
\text { III }\end{array}$ & $\mathrm{H}$ value & $\begin{array}{l}\text { Patch } \\
\text { I }\end{array}$ & $\begin{array}{c}\text { Patch } \\
\text { II }\end{array}$ & $\begin{array}{c}\text { Patch } \\
\text { III }\end{array}$ & $\begin{array}{c}\mathrm{H} \\
\text { value }\end{array}$ \\
\hline \multirow{4}{*}{ 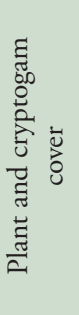 } & 2014 & $\begin{array}{c}96.6 \\
(90-100)\end{array}$ & $\begin{array}{c}98.0 \\
(90-100)\end{array}$ & $\begin{array}{c}98.7 \\
(97-100)\end{array}$ & $0.9^{\mathrm{ns}}$ & $\begin{array}{c}97.1 \\
(90-100)\end{array}$ & $\begin{array}{c}98.2 \\
(90-100)\end{array}$ & $\begin{array}{c}99.0 \\
(97-100)\end{array}$ & $0.3^{\mathrm{ns}}$ \\
\hline & 2015 & $\begin{array}{c}97.3 \\
(90-100)\end{array}$ & $\begin{array}{c}99.2 \\
(98-100)\end{array}$ & $\begin{array}{c}99.0 \\
(97-100)\end{array}$ & $1.6^{\mathrm{ns}}$ & $\begin{array}{c}97.8 \\
(90-100)\end{array}$ & $\begin{array}{c}99.0 \\
(90-100)\end{array}$ & $\begin{array}{c}99.1 \\
(97-100)\end{array}$ & $0.6^{\mathrm{ns}}$ \\
\hline & 2016 & $\begin{array}{c}98.0 \\
(95-100)\end{array}$ & $\begin{array}{c}99.3 \\
(98-100)\end{array}$ & $\begin{array}{c}99.3 \\
(97-100)\end{array}$ & $2.6^{\mathrm{ns}}$ & $\begin{array}{c}98.5 \\
(95-100)\end{array}$ & $\begin{array}{c}99.4 \\
(98-100)\end{array}$ & $\begin{array}{c}99.3 \\
(97-100)\end{array}$ & $0.9^{\text {ns }}$ \\
\hline & $\mathrm{H}$ value & $0.8^{\text {ns }}$ & $0.4^{\mathrm{ns}}$ & $3.4^{\mathrm{ns}}$ & & $0.4^{\mathrm{ns}}$ & $0.03^{\text {ns }}$ & $0.7^{\mathrm{ns}}$ & \\
\hline \multirow{4}{*}{ 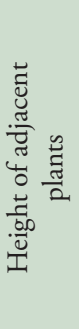 } & 2014 & $\begin{array}{c}40.4 \\
(12-67)\end{array}$ & $\begin{array}{c}54.2 \\
(14-105)\end{array}$ & $\begin{array}{c}77.2 \\
(21-178)\end{array}$ & $\begin{array}{c}8.1 \\
*\end{array}$ & $\begin{array}{c}38.7 \\
(10-72)\end{array}$ & $\begin{array}{c}47.5 \\
(13-101)\end{array}$ & $\begin{array}{c}84.3 \\
(22-183)\end{array}$ & $\begin{array}{l}9.4 \\
* *\end{array}$ \\
\hline & 2015 & $\begin{array}{c}42.9 \\
(25-69)\end{array}$ & $\begin{array}{c}58.3 \\
(14-119)\end{array}$ & $\begin{array}{c}79.6 \\
(11-178)\end{array}$ & $\begin{array}{c}8.0 \\
*\end{array}$ & $\begin{array}{c}42.0 \\
(9-77)\end{array}$ & $\begin{array}{c}51.8 \\
(17-112)\end{array}$ & $\begin{array}{c}90.1 \\
(42-178)\end{array}$ & $\begin{array}{c}13.2 \\
* *\end{array}$ \\
\hline & 2016 & $\begin{array}{c}45.1 \\
(21-72)\end{array}$ & $\begin{array}{c}61.1 \\
(18-121)\end{array}$ & $\begin{array}{c}84.2 \\
(23-186)\end{array}$ & $\begin{array}{l}9.8 \\
* *\end{array}$ & $\begin{array}{c}45.3 \\
(15-83)\end{array}$ & $\begin{array}{c}58.4 \\
(21-214)\end{array}$ & $\begin{array}{c}93.6 \\
(34-186)\end{array}$ & $\begin{array}{c}13.6 \\
* *\end{array}$ \\
\hline & $H$ value & $0.9^{\mathrm{ns}}$ & $0.3^{\mathrm{ns}}$ & $0.7^{\mathrm{ns}}$ & & $1.3^{\mathrm{ns}}$ & $2.7^{\mathrm{ns}}$ & $1.6^{\mathrm{ns}}$ & \\
\hline \multirow{4}{*}{ 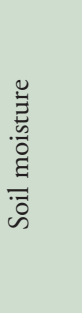 } & 2014 & $\begin{array}{c}5.8 \\
(3-7)\end{array}$ & $\begin{array}{c}8.2 \\
(7-9)\end{array}$ & $\begin{array}{c}7.8 \\
(5-9)\end{array}$ & $\begin{array}{l}34.7 \\
* * *\end{array}$ & $\begin{array}{c}5.6 \\
(3-7)\end{array}$ & $\begin{array}{c}8.1 \\
(7-9)\end{array}$ & $\begin{array}{c}7.8 \\
(5-9)\end{array}$ & $\begin{array}{c}36.9 \\
* * *\end{array}$ \\
\hline & 2015 & $\begin{array}{c}5.9 \\
(3-7)\end{array}$ & $\begin{array}{c}8.3 \\
(7-9)\end{array}$ & $\begin{array}{c}7.9 \\
(5-9)\end{array}$ & $\begin{array}{c}32.2 \\
* * *\end{array}$ & $\begin{array}{c}5.8 \\
(4-7)\end{array}$ & $\begin{array}{c}8.2 \\
(7-9)\end{array}$ & $\begin{array}{c}7.9 \\
(5-9)\end{array}$ & $\begin{array}{c}35.8 \\
* * *\end{array}$ \\
\hline & 2016 & $\begin{array}{c}6.3 \\
(5-7)\end{array}$ & $\begin{array}{c}8.3 \\
(8-9)\end{array}$ & $\begin{array}{c}8.2 \\
(7-9)\end{array}$ & $\begin{array}{l}35.0 \\
* * *\end{array}$ & $\begin{array}{c}6.0 \\
(3-7)\end{array}$ & $\begin{array}{c}8.3 \\
(7-9)\end{array}$ & $\begin{array}{c}8.0 \\
(5-9)\end{array}$ & $\begin{array}{c}35.0 \\
* * *\end{array}$ \\
\hline & $\mathrm{H}$ value & $2.4^{\mathrm{ns}}$ & $0.6^{\mathrm{ns}}$ & $1.1^{\mathrm{ns}}$ & & $1.4^{\mathrm{ns}}$ & $0.9^{\mathrm{ns}}$ & $1.3^{\mathrm{ns}}$ & \\
\hline \multirow{4}{*}{ 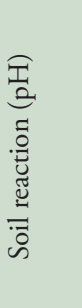 } & 2014 & $\begin{array}{c}6.5 \\
(6-7)\end{array}$ & $\begin{array}{c}8.0 \\
(7-9)\end{array}$ & $\begin{array}{c}8.1 \\
(7-9)\end{array}$ & $\begin{array}{c}33.1 \\
* * *\end{array}$ & $\begin{array}{c}6.8 \\
(6-7)\end{array}$ & $\begin{array}{c}8.3 \\
(8-9)\end{array}$ & $\begin{array}{c}7.6 \\
(7-8)\end{array}$ & $\begin{array}{l}40.7 \\
* * *\end{array}$ \\
\hline & 2015 & $\begin{array}{c}6.4 \\
(6-7)\end{array}$ & $\begin{array}{c}8.3 \\
(8-9)\end{array}$ & $\begin{array}{c}8.2 \\
(7-9)\end{array}$ & $\begin{array}{l}40.7 \\
* * *\end{array}$ & $\begin{array}{c}6.9 \\
(6-8)\end{array}$ & $\begin{array}{c}8.5 \\
(8-9)\end{array}$ & $\begin{array}{c}7.7 \\
(7-8)\end{array}$ & $\begin{array}{c}37.3 \\
* * *\end{array}$ \\
\hline & 2016 & $\begin{array}{c}6.8 \\
(6-8)\end{array}$ & $\begin{array}{c}8.2 \\
(7-9)\end{array}$ & $\begin{array}{c}8.0 \\
(7-9)\end{array}$ & $\begin{array}{c}27.2 \\
* * *\end{array}$ & $\begin{array}{c}7.3 \\
(6-8)\end{array}$ & $\begin{array}{c}8.5 \\
(8-9)\end{array}$ & $\begin{array}{c}7.9 \\
(7-9)\end{array}$ & $\begin{array}{c}24.4 \\
* * *\end{array}$ \\
\hline & $\mathrm{H}$ value & $3.4^{\mathrm{ns}}$ & $3.6^{\mathrm{ns}}$ & $0.6^{\mathrm{ns}}$ & & $6.9^{\mathrm{ns}}$ & $1.7^{\mathrm{ns}}$ & $2.8^{\mathrm{ns}}$ & \\
\hline
\end{tabular}

In 2014, the abundance of individuals and ramet clusters of Valeriana officinalis var. officinalis was studied in all the study patches. In the years 2014-2016, the number of individuals and ramet clusters were inventoried and labelled with plastic pegs in the permanent plots measuring $100 \mathrm{~m}^{2}$. The following traits were investigated in the marked individuals and ramet clusters: (i) the number of leaves per rosette and total length of petiole and blade of the longest leaf; (ii) the number of flowering stems; (iii) the height of all the flowering stems (from ground level to basis of inflorescence); and (iv) the estimated number of flowers per flowering stem calculated by multiplication of the number of flowers recorded on an average branch by the number of branches in inflorescence.

\section{Statistical analysis}

The normal distribution of each group of the untransformed data (from a particular Patch and year) was tested using the Kolmogorov-Smirnov test, while homogeneity of variance was tested using the Levene test at the significance level of $\mathrm{P}<0.05$. As the values in some groups were not consistent with normal distribution, and the variance was not homogeneous, the analysis was based mainly on non-parametric tests. The Kruskal-Wallis $\mathrm{H}$ test was applied to check whether there were any significant differences among the patches located within each study area and among consecutive years in: (i) plant and cryptogam cover, height of standing vegetation, soil humidity and soil $\mathrm{pH}$; (ii) number of aboveground units in 
individuals/ramet clusters; (iii) number of radical leaves in individuals and ramet clusters; (iv) the length of the longest radical leaf; (v) the number of flowering stems in the generative individuals and ramet clusters, (vi) the height of the flowering stems; and (vii) the number of flowers. The aforementioned analyses were performed using the STATISTICA 12 software package. The interactive chi square test calculator (31) was applied to check whether there were significant differences among the patches and years regarding the share of vegetative and generative individuals and ramet clusters.

\section{RESULTS}

\section{Habitat conditions}

The plant and cryptogam cover did not differ among the patches within each study area, as well as among consecutive years. The height of the neighbouring plants, soil reaction and soil moisture did not show temporal variability, while they presented spatial diversity and augmented from Patch I, via Patch II, to Patch III (Table 2).

\section{Population traits}

In the study area $A$ the total abundance of populations of Valeriana officinalis var. officinalis occurring in subsequent patches reached 143,172 and 118, respectively, whereas in the study area B it achieved 152, 193 and 107. The constant abundance of individuals and ramet clusters within study plots during the whole study period reached 46, 49 and 16 in successive patches located within study area A, and respectively 37,38 and 21 in study area B. Seedlings and juveniles were not found within both study areas, the share of vegetative individuals diminished, while the percentage of generative individuals and ramet clusters augmented gradually in successive patches and in consecutive years (Figure 2).

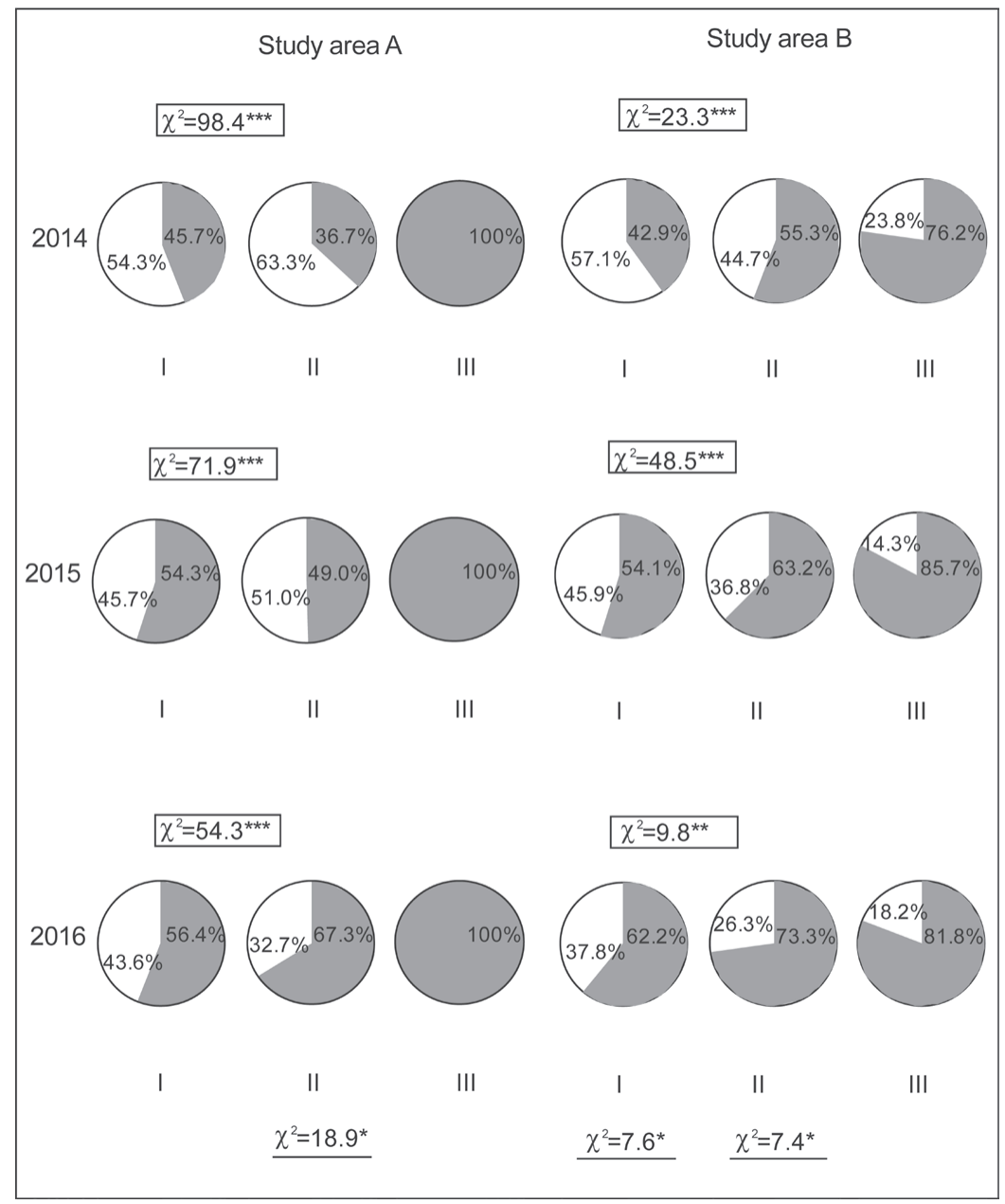

Figure 2. The share of vegetative (white) and generative (grey) individuals and ramet clusters of Valeriana officinalis var. officinalis occurring in permanent plots located in Patches dominated by low-and medium-growing perennials (I), tall-growing perennials (II), as well as tallgrowing perennials and shrubs (III) in study areas A and B in the years 2014-2016. Symbols mean the level of statistical significance (the $\chi^{2}$ test): ${ }^{*} P \leq 0.05,{ }^{*}-P<0.01,{ }^{* *}-P<0.001$; the not significant values were omitted. The values in frames mean the differences among Patches in particular study area, while underlined values mean the differences among consecutive years. 
Table 3. The mean values (range) of number of leaves in rosettes and length (cm) of the longest rosette leaf in vegetative individuals of Valeriana officinalis var. officinalis occurring in permanent plots located in Patches with considerable share of low-and medium-growing perennials (I), tall-growing perennials (II), as well as tall-growing perennials and shrubs (III) in study areas A and B in the years 2014-2016. The meaning of symbols of the level of statistical significance (the Mann-Whitney U test, the Kruskal-Wallis H test) as in Table 2.

\begin{tabular}{|c|c|c|c|c|c|c|c|c|c|}
\hline \multirow{2}{*}{ Trait } & \multirow{2}{*}{ Year } & \multicolumn{3}{|c|}{ Study area A } & \multirow[t]{2}{*}{$\mathrm{U}$ test } & \multicolumn{3}{|c|}{ Study area B } & \multirow[t]{2}{*}{$\mathrm{H}$ test } \\
\hline & & Patch I & Patch II & Patch III & & Patch I & Patch II & Patch III & \\
\hline \multirow{3}{*}{$\begin{array}{l}\text { Number of } \\
\text { leaves }\end{array}$} & 2014 & $\begin{array}{c}4.5 \\
(1-10)\end{array}$ & $\begin{array}{c}7.5 \\
(1-15)\end{array}$ & - & $2.3^{*}$ & $\begin{array}{c}5.0 \\
(1-10)\end{array}$ & $\begin{array}{c}9.2 \\
(3-15)\end{array}$ & $\begin{array}{c}8.6 \\
(6-12)\end{array}$ & $10.1^{* *}$ \\
\hline & 2015 & $\begin{array}{c}5.4 \\
(2-10)\end{array}$ & $\begin{array}{c}9.1 \\
(3-20)\end{array}$ & - & $2.7^{* *}$ & $\begin{array}{c}5.9 \\
(2-10)\end{array}$ & $\begin{array}{c}8.6 \\
(5-12)\end{array}$ & $\begin{array}{c}10.0 \\
(8-11)\end{array}$ & $9.2^{*}$ \\
\hline & 2016 & $\begin{array}{c}7.5 \\
(2-13)\end{array}$ & $\begin{array}{c}10.1 \\
(10-22)\end{array}$ & - & $1.5^{\mathrm{ns}}$ & $\begin{array}{c}6.3 \\
(1-12)\end{array}$ & $\begin{array}{c}8.6 \\
(5-12)\end{array}$ & $\begin{array}{c}6.3 \\
(4-8)\end{array}$ & $4.7^{\mathrm{ns}}$ \\
\hline $\mathrm{H}$ test & & $4.8^{\text {ns }}$ & $5.6^{\mathrm{ns}}$ & & & $3.9^{\text {ns }}$ & $4.1^{\mathrm{ns}}$ & $6.7^{\mathrm{ns}}$ & \\
\hline \multirow{3}{*}{$\begin{array}{l}\text { The length of } \\
\text { the longest } \\
\text { leaf }\end{array}$} & 2014 & $\begin{array}{c}32.3 \\
(17-46)\end{array}$ & $\begin{array}{c}36.1 \\
(16-52)\end{array}$ & - & $1.65^{\mathrm{ns}}$ & $\begin{array}{c}34.7 \\
(17-52)\end{array}$ & $\begin{array}{c}40.8 \\
(27-51)\end{array}$ & $\begin{array}{c}44.6 \\
(39-51)\end{array}$ & $4.2^{\mathrm{ns}}$ \\
\hline & 2015 & $\begin{array}{c}31.5 \\
(14-45)\end{array}$ & $\begin{array}{c}35.3 \\
(18-55)\end{array}$ & - & $-1.63^{\mathrm{ns}}$ & $\begin{array}{c}35.7 \\
(19-51)\end{array}$ & $\begin{array}{c}43.8 \\
(35-51)\end{array}$ & $\begin{array}{c}38.0 \\
(32-48)\end{array}$ & $3.2^{\mathrm{ns}}$ \\
\hline & 2016 & $\begin{array}{c}31.8 \\
(16-46)\end{array}$ & $\begin{array}{c}41.8 \\
(33-56)\end{array}$ & - & $-2.1^{*}$ & $\begin{array}{c}37.0 \\
(22-49)\end{array}$ & $\begin{array}{c}44.4 \\
(37-51)\end{array}$ & $\begin{array}{c}36.8 \\
(32-44)\end{array}$ & $5.6^{\mathrm{ns}}$ \\
\hline $\mathrm{H}$ test & & $0.4^{\mathrm{ns}}$ & $1.2^{\mathrm{ns}}$ & & & $0.4^{\mathrm{ns}}$ & $1.6^{\mathrm{ns}}$ & $3.3^{\text {ns }}$ & \\
\hline
\end{tabular}

Table 4. The mean values (range) of number of ramets, number of leaves in rosettes and length (cm) of the longest rosette leaf in in generative individuals and ramet clusters of Valeriana officinalis var. officinalis occurring in permanent plots located in Patches with considerable share of low-and medium-growing perennials (I), tall-growing perennials (II), as well as tall-growing perennials and shrubs (III) in study areas A and B in the years 2014-2016. The meaning of symbols of the level of statistical significance (the Kruskal-Wallis $H$ test) as in Table 2.

\begin{tabular}{|c|c|c|c|c|c|c|c|c|c|}
\hline \multirow{2}{*}{ Trait } & \multirow{2}{*}{ Year } & \multicolumn{3}{|c|}{ Study area A } & \multirow[t]{2}{*}{$\mathrm{H}$ test } & \multicolumn{3}{|c|}{ Study area B } & \multirow[t]{2}{*}{$\mathrm{H}$ test } \\
\hline & & Patch I & Patch II & Patch III & & Patch I & Patch II & Patch III & \\
\hline \multirow{3}{*}{$\begin{array}{l}\text { Number } \\
\text { of ramets }\end{array}$} & 2014 & $\begin{array}{c}2.0 \\
(1-3)\end{array}$ & $\begin{array}{c}2.5 \\
(1-4)\end{array}$ & $\begin{array}{c}2.7 \\
(1-5)\end{array}$ & $7.6^{*}$ & $\begin{array}{c}1.8 \\
(1-3)\end{array}$ & $\begin{array}{c}2.5 \\
(1-4)\end{array}$ & $\begin{array}{c}2.9 \\
(2-4)\end{array}$ & $14.9^{* * *}$ \\
\hline & 2015 & $\begin{array}{c}2.3 \\
(1-4)\end{array}$ & $\begin{array}{c}2.8 \\
(2-4)\end{array}$ & $\begin{array}{c}3.0 \\
(2-5)\end{array}$ & $7.9^{*}$ & $\begin{array}{c}1.9 \\
(1-3)\end{array}$ & $\begin{array}{c}2.5 \\
(1-4)\end{array}$ & $\begin{array}{c}2.7 \\
(2-3)\end{array}$ & $16.2^{* * *}$ \\
\hline & 2016 & $\begin{array}{c}2.4 \\
(2-5)\end{array}$ & $\begin{array}{c}2.6 \\
(2-5)\end{array}$ & $\begin{array}{c}3.3 \\
(2-4)\end{array}$ & $7.9^{*}$ & $\begin{array}{c}2.1 \\
(1-4)\end{array}$ & $\begin{array}{c}2.4 \\
(1-4)\end{array}$ & $\begin{array}{c}2.8 \\
(1-4)\end{array}$ & $9.9^{*}$ \\
\hline $\mathrm{H}$ test & & $4.9^{\text {ns }}$ & $0.6^{\mathrm{ns}}$ & $4.1^{\mathrm{ns}}$ & & $0.4^{\mathrm{ns}}$ & $0.6^{\mathrm{ns}}$ & $0.5^{\mathrm{ns}}$ & \\
\hline \multirow{3}{*}{$\begin{array}{l}\text { Number } \\
\text { of leaves }\end{array}$} & 2014 & $\begin{array}{c}5.2 \\
(1-15)\end{array}$ & $\begin{array}{c}8.4 \\
(2-18)\end{array}$ & $\begin{array}{c}4.5 \\
(1-12)\end{array}$ & $8.4^{*}$ & $\begin{array}{c}4.4 \\
(1-11)\end{array}$ & $\begin{array}{c}7.5 \\
(2-14)\end{array}$ & $\begin{array}{c}6.8 \\
(2-11)\end{array}$ & $6.2^{*}$ \\
\hline & 2015 & $\begin{array}{c}6.0 \\
(1-16)\end{array}$ & $\begin{array}{c}9.7 \\
(1-22)\end{array}$ & $\begin{array}{c}5.8 \\
(3-13)\end{array}$ & $9.9^{*}$ & $\begin{array}{c}3.4 \\
(2-10)\end{array}$ & $\begin{array}{c}8.7 \\
(2-16)\end{array}$ & $\begin{array}{c}9.0 \\
(5-13)\end{array}$ & $23.8^{* * *}$ \\
\hline & 2016 & $\begin{array}{c}7.1 \\
(1-18) \\
\end{array}$ & $\begin{array}{c}10.9 \\
(3-23) \\
\end{array}$ & $\begin{array}{c}8.4 \\
(2-15) \\
\end{array}$ & $10.5^{* *}$ & $\begin{array}{c}5.5 \\
(2-12) \\
\end{array}$ & $\begin{array}{c}8.6 \\
(2-12) \\
\end{array}$ & $\begin{array}{c}8.5 \\
(4-12) \\
\end{array}$ & $11.5^{* *}$ \\
\hline $\mathrm{H}$ test & & $5.9^{\mathrm{ns}}$ & $4.8^{\mathrm{ns}}$ & $11.0^{* *}$ & & $3.8^{\mathrm{ns}}$ & $4.2^{\mathrm{ns}}$ & $5.6^{*}$ & \\
\hline \multirow{3}{*}{$\begin{array}{l}\text { The length } \\
\text { of the longest } \\
\text { leaf }\end{array}$} & 2014 & $\begin{array}{c}38.6 \\
(24-60)\end{array}$ & $\begin{array}{c}48.6 \\
(36-66)\end{array}$ & $\begin{array}{c}53.4 \\
(17-68)\end{array}$ & $10 .^{* *}$ & $\begin{array}{c}31.3 \\
(24-53)\end{array}$ & $\begin{array}{c}44.0 \\
(23-66)\end{array}$ & $\begin{array}{c}49.0 \\
(17-68)\end{array}$ & $6.2^{*}$ \\
\hline & 2015 & $\begin{array}{c}39.1 \\
(24-63)\end{array}$ & $\begin{array}{c}51.2 \\
(32-58)\end{array}$ & $\begin{array}{c}55.4 \\
(39-64)\end{array}$ & $16.1^{* * *}$ & $\begin{array}{c}35.5 \\
(24-48)\end{array}$ & $\begin{array}{c}45.0 \\
(26-56)\end{array}$ & $\begin{array}{c}47.2 \\
(23-60)\end{array}$ & $23.8^{* * *}$ \\
\hline & 2016 & $\begin{array}{c}43.3 \\
(24-63)\end{array}$ & $\begin{array}{c}43.2 \\
(35-60)\end{array}$ & $\begin{array}{c}58.6 \\
(42-64)\end{array}$ & $30.9^{* * *}$ & $\begin{array}{c}42.4 \\
(22-51)\end{array}$ & $\begin{array}{c}43.7 \\
(28-69)\end{array}$ & $\begin{array}{c}48.2 \\
(20-58)\end{array}$ & $11.5^{* *}$ \\
\hline $\mathrm{H}$ test & & $5.4^{\mathrm{ns}}$ & $5.3^{\mathrm{ns}}$ & $4.7^{\mathrm{ns}}$ & & $6.0^{\mathrm{ns}}$ & $0.7^{\mathrm{ns}}$ & $3.7^{\mathrm{ns}}$ & \\
\hline
\end{tabular}




\section{Individual traits}

In both study areas similar tendencies were observed. All vegetative individuals created one ramet (rosette of leaves) during the whole study period. The number of basal leaves did not show temporal variability, but it presented remarkable spatial variability, achieving much lower values in Patch I, than in Patch II and Patch III. The length of the longest leaf did not show any spatial or temporal variability (Table 3 ).

The number of ramets in generative individuals and ramet clusters was similar in consecutive years, whereas it differed substantially among the patches and augmented from Patch I, via Patch II, to Patch III (Table 4). In all the subpopulations during the whole study period, the generative individuals and ramet clusters created solely one leaf rosette. The greatest number of radical leaves was observed in Patch II or in Patch III. Furthermore, in Patch III the gradual temporal increase of the number of rosette leaves was observed (Table 4). The length of the longest radical leaf (Table 4), number of flowering stems (Table 5), height of the longest flowering stems (Table 5) and the number of flowers (Table 5) reached substantially lower values in Patch I than in the other patches. Moreover, the two latter traits showed a remarkable temporal variability in Patch III.

\section{DISCUSSION}

The observed lack of temporal changes of the investigated habitat conditions might be caused by the short study period. The similar, substantial plant and cryptogam cover within all the studied patches within both study areas might be an effect of an abundant occurrence of successfully spreading clonal species (32, and literature cited therein), as well as the lack of animal- or man-made disturbances to the continuous plant canopy such as trampling, grazing, browsing, wallowing, raking and many others (cf. 33). Of note is the full plant cover also observed in other communities belonging to the Molinietalia order, namely abandoned meadows representing different stages of the secondary succession and various floristic composition classified to the alliance Calthion palustris Tx. 1937 (34) and Molinion caeruleae Koch 1926 (35).

The observed much lower height of neighbouring plants in Patch I than in the other ones is linked to the

Table 5. The mean values (range) of number of flowering stems, height $(\mathrm{cm})$ of the longest flowering stems and estimated number of flowers created per generative individuals and ramet clusters of Valeriana officinalis var. officinalis occurring in permanent plots located in Patches with considerable share of low-and medium-growing perennials (I), tall-growing perennials (II), as well as tall-growing perennials and shrubs (III) in study areas $A$ and $B$ in the years 2014-2016. The meaning of symbols of the level of statistical significance (the Kruskal-Wallis $H$ test) as in Table 2.

\begin{tabular}{|c|c|c|c|c|c|c|c|c|c|}
\hline \multirow{2}{*}{ Trait } & \multirow{2}{*}{ Year } & \multicolumn{3}{|c|}{ Study area A } & \multirow[t]{2}{*}{$\mathrm{H}$ test } & \multicolumn{3}{|c|}{ Study area B } & \multirow[t]{2}{*}{ H test } \\
\hline & & Patch I & Patch II & Patch III & & Patch I & Patch II & Patch III & \\
\hline \multirow{3}{*}{$\begin{array}{l}\text { Number } \\
\text { of stems }\end{array}$} & 2014 & $\begin{array}{c}1.2 \\
(1-2)\end{array}$ & $\begin{array}{c}1.7 \\
(1-3)\end{array}$ & $\begin{array}{c}1.4 \\
(1-8)\end{array}$ & $\begin{array}{c}8.4 \\
*\end{array}$ & $\begin{array}{c}1.1 \\
(1-2)\end{array}$ & $\begin{array}{c}1.6 \\
(1-3)\end{array}$ & $\begin{array}{c}1.9 \\
(1-3)\end{array}$ & $13.6^{* *}$ \\
\hline & 2015 & $\begin{array}{c}1.3 \\
(1-3)\end{array}$ & $\begin{array}{c}2.8 \\
(2-8)\end{array}$ & $\begin{array}{c}2.0 \\
(1-4)\end{array}$ & $\begin{array}{l}7.3 \\
*\end{array}$ & $\begin{array}{c}1.2 \\
(1-2)\end{array}$ & $\begin{array}{c}1.7 \\
(1-3)\end{array}$ & $\begin{array}{c}1.8 \\
(1-3)\end{array}$ & $10.8^{* *}$ \\
\hline & 2016 & $\begin{array}{c}1.4 \\
(1-4)\end{array}$ & $\begin{array}{c}1.6 \\
(1-3)\end{array}$ & $\begin{array}{c}2.3 \\
(1-3)\end{array}$ & $15.1^{*}$ & $\begin{array}{c}1.3 \\
(1-3)\end{array}$ & $\begin{array}{c}1.5 \\
(1-2)\end{array}$ & $\begin{array}{c}1.9 \\
(1-4)\end{array}$ & $27.6^{* *}$ \\
\hline $\mathrm{H}$ test & & $2.7^{\mathrm{ns}}$ & $3.8^{\mathrm{ns}}$ & $3.9^{\mathrm{ns}}$ & & $3.7^{\mathrm{ns}}$ & $1.5^{\mathrm{ns}}$ & $0.5^{\mathrm{ns}}$ & \\
\hline \multirow{3}{*}{$\begin{array}{l}\text { Length } \\
\text { of the lon- } \\
\text { gest stem }\end{array}$} & 2014 & $\begin{array}{c}89.8 \\
(72-103)\end{array}$ & $\begin{array}{c}108.7 \\
(87-132)\end{array}$ & $\begin{array}{c}103.4 \\
(80-132)\end{array}$ & $27.6^{* * *}$ & $\begin{array}{c}83.3 \\
(57-100)\end{array}$ & $\begin{array}{c}108.7 \\
(84-136)\end{array}$ & $\begin{array}{c}104.1 \\
(80-133)\end{array}$ & $32.6^{* * *}$ \\
\hline & 2015 & $\begin{array}{c}90.9 \\
(72-112)\end{array}$ & $\begin{array}{c}111.2 \\
(87-130)\end{array}$ & $\begin{array}{c}109.4 \\
(87-124)\end{array}$ & $42.3^{* * *}$ & $\begin{array}{c}83.7 \\
(71-100)\end{array}$ & $\begin{array}{c}110.6 \\
(80-227)\end{array}$ & $\begin{array}{c}100.8 \\
(75-126)\end{array}$ & $40.4^{* * *}$ \\
\hline & 2016 & $\begin{array}{c}94.4 \\
(78-112)\end{array}$ & $\begin{array}{c}114.7 \\
(78-142)\end{array}$ & $\begin{array}{c}111.4 \\
(83-142)\end{array}$ & $46.8^{* * *}$ & $\begin{array}{c}88.4 \\
(75-108)\end{array}$ & $\begin{array}{c}118.9 \\
(76-132)\end{array}$ & $\begin{array}{c}112.8 \\
(78-142)\end{array}$ & $39.8^{* * *}$ \\
\hline $\mathrm{H}$ test & & $4.8^{\text {ns }}$ & $3.2^{\mathrm{ns}}$ & $8.3^{*}$ & & $1.9^{\text {ns }}$ & $3.6^{\mathrm{ns}}$ & $4.9^{*}$ & \\
\hline \multirow{3}{*}{$\begin{array}{l}\text { Number } \\
\text { of flowers } \\
\text { per stem }\end{array}$} & 2014 & $\begin{array}{c}199.1 \\
(60-460)\end{array}$ & $\begin{array}{c}382.9 \\
(140-860)\end{array}$ & $\begin{array}{c}260.7 \\
(60-890)\end{array}$ & $17.3^{* * *}$ & $\begin{array}{c}190.6 \\
(40-380)\end{array}$ & $\begin{array}{c}382.4 \\
(190-780)\end{array}$ & $\begin{array}{c}328.7 \\
(120-1000)\end{array}$ & $17.3^{* * *}$ \\
\hline & 2015 & $\begin{array}{c}211.6 \\
(60-460)\end{array}$ & $\begin{array}{c}383.8 \\
(220-860)\end{array}$ & $\begin{array}{c}301.6 \\
(80-1000)\end{array}$ & $22.2^{* * *}$ & $\begin{array}{c}218.3 \\
(60-490)\end{array}$ & $\begin{array}{c}375.9 \\
(190-780)\end{array}$ & $\begin{array}{c}341.4 \\
(120-780)\end{array}$ & $18.4^{* * *}$ \\
\hline & 2016 & $\begin{array}{c}241.4 \\
(120-780)\end{array}$ & $\begin{array}{c}360.0 \\
(150-740)\end{array}$ & $\begin{array}{c}313.9 \\
(60-1000)\end{array}$ & $13.9^{* *}$ & $\begin{array}{c}222.8 \\
(60-560)\end{array}$ & $\begin{array}{c}370.0 \\
(180-780)\end{array}$ & $\begin{array}{c}432.7 \\
(60-780)\end{array}$ & $23.1^{* * *}$ \\
\hline $\mathrm{H}$ test & & $2.5^{\mathrm{ns}}$ & $5.3^{\text {ns }}$ & $27.9^{* * *}$ & & $6.9^{\text {ns }}$ & $1.0^{\mathrm{ns}}$ & $41.1^{* * *}$ & \\
\hline
\end{tabular}


character of the species prevailing in the plant canopy. The augmentation of the mean height of standing vegetation in respect of different dominants was already found in meadows from the alliance Molinion (36-38).

Previous observations have shown that communities with domination of Filipendula ulmaria might develop on soil with moderate humidity (39), as well as in highly silty soils (40). The presented studies also proved the substantial variability of ground moisture among the patches within both study area (5.6-6.3 in Patch I, 8.1-8.3 in Patch II and 7.8-8.2 in Patch III), which might be shaped by the architecture of the plants existing in the standing vegetation. The tall-growing macroforbs (i.e. Filipendula ulmaria, Lythrum salicaria), large-tussock grasses (e.g. Deschampsia caespitosa) and shrubs such as Salix cinerea and Salix rosmarionofolia, occurring abundantly in Patches II and III might contribute to an increase of soil moisture through the creation of numerous stems, with the dense leaf canopy limiting water evaporation and/or production of substantial amount of litter leading to water retention. Such a scenario was already found in abandoned meadows from the alliance Molinion (41).

The performed studies, showing much lower values of soil pH in Patch I than in Patches II and III, seem to correspond with the findings of Haynes (42), who found that the occurrence of leguminous crops in standing vegetation might contribute to a decrease of soil $\mathrm{pH}$. The performed investigations are in contrast to the observations of other authors $(43,44)$ demonstrating the decrease of soil reaction in the course of succession in abandoned meadows. A similar phenomenon was also recorded in experimentally fenced, non-grazed meadows (45) and grasslands (46). According to Singh and Gupta (47), the decrease of soil $\mathrm{pH}$ beneath the litter is caused by the carbonic and weak organic acids liberated as an effect of decomposition of necromass and soil organic matter.

The similar patterns of trait variability among the study patches situated in both study areas indicate the repeatability of the observed scenarios. The observed greater abundance of Valeriana officinalis var. officinalis populations in patches dominated by low- and mediumstatured species might suggest the former occurrence of safe sites for seedling recruitment. Such a scenario was observed by Alyemeni, Sher (48) in populations of Valeriana jatamansi, in which the abundance augments in more grazed and trampled areas near a temporary shepherd's hut and on areas with cattle dung manure.

The lack of individuals in pre-reproductive stages and the increasing share of generative individuals and ramet clusters at the expense of vegetative genets in consecutive study sites and in subsequent years observed in subpopulations of Valeriana officinalis var. officinalis, was also noticed in several other species inhabiting humid and wet meadows in the course of secondary succession. Such a phenomenon was observed in populations of Carex cespitosa (49), Gentiana pneumonanthe (50-52), Succisa pratensis
(37) and Gladiolus imbricatus (36). A comparison of the structure of the developmental stages of $V$. officinals in consecutive years suggests that vegetative individuals might retard maturation. Such a phenomenon is named "Oskar syndrome" (53), triggered by unfavourable site conditions, was observed in several tree species, in which seedlings delay the production of branches, flowers and seed until the canopy becomes open due to death of other trees. This delay of maturation was also noticed in herbaceous species inhabiting meadows in the course of succession, such as Cirsium palustre (54).

The performed observations support the findings of Ford (55), who reported that the surrounding environment shapes the architecture of an individual. The lower dimensions of leaf rosettes of $V$. officinalis var. officinalis noted in sites dominated by low- and medium-statured perennials than in places prevailed by tall-growing species correspond with the investigations conducted in populations of other congeners. Rather et al. (56), as well as Mukherjee and Chakraborty (57) argued that in forests with dense plant canopy, individuals of $V$. jatamansi create larger radical leaves than plants growing under open sunny conditions on rocky slopes.

The observed greater number of ramets per cluster in sites overgrown by tall-growing perennials and shrubs might be the result of successful vegetative growth. The effective multiplication of the aboveground units and enlargement of underground organs, despite the proximity of strong competitors, was found in populations of numerous macroforbs such as Cirsium oleraceum and $C$. rivulare (58), Filipendula ulmaria (59-61), as well as Lythrum salicaria (61). The aforementioned authors emphasise that the effective vegetative growth contributes to the persistence of populations in a colonised site.

The obtained results proving that the number and length of flowering stems, as well as the number of flowers augments in subsequent study sites, is in contrast to previous findings (13), proving that number of flowering stems in Valeriana offcinalis var. officinalis augments with diminishing plant density. On the other hand, Rather et al. (56) added that in shady dense habitats, individuals of $\mathrm{V}$. jatamansi create longer flowering stems.

The observed substantial rise in the number of rosette leaves, height of flowering stems and number of flowers in generative individuals and ramet clusters in consecutive years, recorded mostly in Patch III, might be a response to augmenting competitive pressure of tall-growing plants occurring in close vicinity. The temporal differences of individual traits especially within sites in advanced secondary succession level were also observed in populations of Succisa pratensis (38).

\section{CONCLUSIONS}

In light of the performed studies, it can be stated that despite the advanced signs of senescence found in all the studied subpopulations of Valeriana officinalis var. offici- 
nalis, their condition seems to be satisfactory. The substantial share of vegetative individuals in sites dominated by low- or medium-statured plants increases the chances for the maintenance of subpopulations in occupied sites. Moreover, the vegetative growth enables the spreading and protection from regression from the colonised locations, especially those overgrown by strong competitors. Furthermore, the substantial dimensions of the flowering stems and the considerable flower production noted in places dominated by tall-growing perennials and shrubs might contribute to successful pollination and, in consequence, to the production of seeds that might also be dispersed into safe sites for seedling recruitment such as gaps (62) or nurse plants (63).

\section{REFERENCES}

1. PETROVSKA BB 2012 Historical review of medicinal plants' usage. Pharmacogn Rev 6 (11): 1-5 https://doi.org/10.4103/0973-7847.95849

2. SINGH R 2015 Medicinal Plants: A Review. J Plant Sci, Special Issue: Medicinal Plants 3 (1): 50-55

3. CHEN S-L, YU H, LUO H-M, WU Q, LI CH-F, STEINMETZ A 2016 Conservation and sustainable use of medicinal plants: problems, progress, and prospects. Chin Med 11: 37-47 https://doi.org/10.1186/s13020-016-0108-7

4. ROSS IA 2005 Medicinal plants of the world (volume 3): chemical constituents, traditional and modern medicinal uses. Humana Press Inc, New Jersey, p. 110-132.

5. MESFIN K, TEKLE G, TESFAY T 2013 Assessment of threatening factors of medicinal plant species in Samre district, southeastern Tigray, northern Ethiopia. J Med Plants Stud 1 (4): 38-42

6. ANONYMOUS 1993 Guidelines on the Conservation of Medicinal Plants The World Health Organization, The World Conservation Union and World Wide Fund for Nature, Geneva, p 38.

7. KATHE W 2006 Revision of the 'guidelines on the conservation of medicinal plants' by WHO, IUCN, WWF and TRAFFIC. In: Bogers RJ, Craker LE, Lange D (eds.), Medicinal and Aromatic Plants, Springer, Netherlands, p. 109-120 https://doi.org/10.1007/1-4020-5449-1_8

8. BARATA AM, ROCHA F, LOPES V, CARVALHO AM 2016 Conservation and sustainable uses of medicinal and aromatic plants genetic resources on the worldwide for human welfare. Ind Crop Prod 88: 8-11 https://doi.org/10.1016/j.indcrop.2016.02.035

9. CZABAJSKA W, JARUZELSKI W, UBYSZ D 1976 New methods in the cultivation of Valeriana officinalis. Planta Med 30 (5): 9-13 https://doi.org/10.1055/s-0028-1097685

10. MORTEZA E, AKBARI GA, SANAVI SAMM, FOGHI B, ABDOLI M, FARAHANI HA 2009 Planting density influence on variation of the essential oil content and compositions in valerian (Valeriana officinalis L.) under different sowing dates. Afr. J. Microbiol. Res 3 (12): 897-902

11. MORTEZA E, AKBARI GA, SANAVI SAMM, FARAHANI HA 2010 Determination of the vegetative and reproductive characteristics of valerian (Valeriana officinalis L.) under sowing dates and planting densities at Iran. J. Med. Plant. Res. 4 (10): 857-861

12. BADI HN, LOTFIZAD M, QUAVANI N, KHAVAZI K 2013 Response of quantity and quality yield of valerian (Valeriana officinalis $\mathrm{L}$.) to application of phosphorous bio/chemical fertilizers. J Med Plants 12 (46): 25-37

13. MONJEZI N, RAZMJO J, KARIMMOJENI H 2015 Valerian (Valeriana officinalis L.) tolerance to some post-emergence herbi- cides. J Plant Prot Res 55 (4): 415-420

https://doi.org/10.1515/jppr-2015-0057

14. GRÄNICHER F, CHRISTEN P, KAPETANIDIS I 1992 Highyield production of valepotriates by hairy root cultures of Valeriana offcinalis L. var. sambucifolia Mikan. Plant Cell Rep 11 (7): 339_ 42 https://doi.org/10.1007/BF00233361

15. GRÄNICHER F, CHRISTEN P, KAPETANIDIS I 1995 Essential oils from normal and hairy roots of Valeriana offcinalis var. sambucifolia. Phytochernistry 40 (5): 1421-1424 https://doi.org/10.1016/0031-9422(95)00492-P

16. WIŚNIEWSKI J, SZCZEPANIK M, KOŁODZIEJ B, KRÓL B 2016 Plantation methods effects on common valerian (Valeriana officinalis) yield and quality. J Anim Plant Sci 26 (1): 177-184

17. SEIDLER-ŁOŻYKOWSKA K, MIELCAREK S, BARANIAK M 2009 Content of essential oil and valerenic acids in valerian (Valeriana offcinalis $\mathrm{L}$.) roots at the selected developmental phases. J Essent Oil Res 21 (5): 413-416 http://dx.doi.org/10.1080/10412905.2009.9700206

18. ANONYMOUS 2013 The Plant List available from: http://www.theplantlist.org/tpl1.1/record/kew-2464616

19. KIRSCHNER, J. \& RAAB-STRAUBE, E. VON 2017+: Valeriana officinalis aggr. - In: Raab-Straube, E. von \& Henning, T. (2017+): Valerianaceae. Euro+Med Plantbase - the information resource for Euro-Mediterranean plant diversity, available from: http://ww2.bgbm.org/EuroPlusMed/query.asp

20. KLIMEŠOVÁ J, KLIMEŠ L 2006 Clo-Pla 3. Database of clonal growth of plants from Central Europe, available from: http://clopla.butbn.cas.cz/

21. ROSTAŃSKI K 1967 Valeriana officinalis L. Kozłek lekarski (Common valerian). In: Pawłowski B. (ed) Flora Polski. Rośliny naczyniow Polski i terenów ościennych (Flora of Poland. Vascular plants of Poland and adjacent territories). Volume IX Dwuliścienne. Zrosłopłatkowe (Dicotyledones. Sympetalous), PWN, WarsawKrakow, p. 348-349 (in Polish)

22. ANONYMOUS 2007 Floral Encounters, available from: http://www.floralencounters.com/Seeds/seed_main.jsp

23. ZAJAC M, ZAJAC A 2009 The geographical elements of native flora of Poland. Institute of Botany, Jagiellonian University, Kraków, p 94.

24. PATOKA J, JAKL J 2010 Biomedically relevant chemical constituents of Valeriana officinalis. J Appl Biomem 8: 11-18 https://doi.org/10.2478/v10136-009-0002-z

25. ALLEN D, BILZ M, LEAMAN DJ, MILLER RM, TIMOSHYNA A, WINDOW J 2014 European Red List of Medicinal Plants. Publications Office of the European Union, Luxembourg, p 63.

26. MOSER D, GYGAX A, BÄUMLER B, WYLER N, PALESE R 2002 Liste Rouge des fougères et plantes à fleurs menaces de Suisse. Office fédéral de l'environnement, des forêts et du paysage Berne, p. 118.

27. CHEFFINGS CM, FARRELL L, DINES TD, JONES RA, LEACH SJ, MCKEAN DR, PEARMAN DA, PRESTON CD, RUMSEY FJ, TAYLOR I 2005 The Vascular Plant Red Data List for Great Britain. Species Status 7. Joint Nature Conservation Committee, Peterborough, p 116.

28. ANONYMOUS 2013 Red List of Albania Flora and Fauna, available from: http://www.nationalredlist.org/red-list-of-albania-floraand-fauna-2013/)

29. STROH PA, LEACH SJ, AUGUST TA, WALKER KJ, PEARMAN DA, RUMSEY FJ, HARROWER CA, FAY MF, MARTIN JP, PANKHURST T, PRESTON CD, TAYLOR I 2014 A Vascular Plant Red List for England, Botanical Society of Britain and Ireland, Bristol, p. 184.

30. JĘDRYCHOWSKI I 2007 Atlas of surroundings of the Campus of the 600th Anniversary of the Restoration of the Jagiellonian 
University. Institute of Geography and Spatial Management, Kraków, p. 71. (in Polish)

31. PREACHER KJ 2001 Calculation for the chi-square test: An interactive calculation tool for chi-square tests of goodness of fit and independence [Computer software], available from: http://quantpsy.org.

32. KLIMEŠOVÁ J, KLIMEŠ L 2007 Bud banks and their role in vegetative regeneration - a literature review and proposal for simple classification and assessment. Perspect Plant Ecol 8: 115-129 https://doi.org/10.1016/j.ppees.2006.10.002

33. SOUSA WP 1984 The role of disturbance in natural communities. Ann Rev Ecol Syst 15: 353-391 https://doi.org/10.1146/annurev.es.15.110184.002033

34. KUCHARSKI L 2015 Vegetation in abandoned meadows in Central Poland: Pilsia Valley. Case study. Acta Sci Pol Agricultura 14 (2): $37-47$

35. WÓJCIK T, JANICKA M 2016 Current state and changes in Molinion meadows from Kostrze environs in Kraków. Ecol. Questions 23: 15-27 http://dx.doi.org/10.12775/EQ.2016.002

36. KOSTRAKIEWICZ-GIERAŁT K 2014 The variability of selected features of Gladiolus imbricatus L. in relation to successive stages of meadow communities following the mowing cessation. Pol J Ecol 62: 307-321 https://doi.org/10.3161/104.062.0210

37. KOSTRAKIEWICZ-GIERAŁT K 2017 Population traits of the rare plant species Succisa pratensis Moench. in meadow overgrowing. Arch Biol Sci. 69 (2): 323-333 https://doi.org/10.2298/ABS160421107K

38. KOSTRAKIEWICZ-GIERAŁT K 2015 The variability of Succisa pratensis Moench individuals and ramet clusters in abandoned Molinietum caeruleae meadows. Ekológia (Bratislava) 34 (3): 216225 https://doi.org/10.1515/eko-2015-0021

39. WARDA M, STAMIROWSKA-KRZACZEK E, KULIK M 2014 Plant communities of grassland from Calthion and Filipendulion alliances in the middle part of the Wieprz valley. Ann UMCS, Sec. E. 69 (4): 120-132

40. WARDA M, STAMIROWSKA-KRZACZEK E, KULIK M 2013 Floristic diversity of selected plant communities on extensive and abandoned grasslands in the Nadwieprzański Landscape Park. J Water Land Dev 19: 77-82 https://doi.org/10.2478/jwld-2013-0019

41. KULIK M 2014 Changes of biodiversity and species composition of Molinia meadow depending on use method. Pol J Environ Stud 23 (3): 773-782

42. HAYNES RJ 1983 Soil acidification induced by leguminous crops. Grass For Sci 38 (1): 1-11. https://doi.org/10.1111/j.1365-2494.1983.tb01614.x

43. MUYS B, LUST N, GRANVAL P 1992 Effects of grassland afforestation with different tree species on earthworm communities, litter decomposition and nutrient status. Soil Biol Biochem 24 (12): 1459-1466 https://doi.org/10.1016/0038-0717(92)90133-I

44. WÓJCIK T, KOTAŃSKA M 2014 Meadow communities with Cirsium canum (1.) All. in the Wielopolka river valley in the Strzyżów Foothills (Western Carpathians). Steciana 18 (2): 37-47 https://doi.org/10.12657/steciana.018.006

45. WU G-L, LIU Z.H, ZHANG L, CHEN JM, HU TM 2010 Longterm fencing improved soil properties and soil organic carbon storage in an alpine swamp meadow of western China. Plant Soil 332 (1-2): 331-337 https://doi.org/10.1007/s11104-010-0299-0

46. DENG L, ZHANG ZN, SHANGGUAN ZP 2014 Long-term fencing effects on plant diversity and soil properties in China. Soil Till Res 137: 7-15 https://doi.org/10.1016/j.still.2013.11.002
47. SINGH JS, GUPTA SR 1977 Plant decomposition and soil respiration in terrestrial ecosystems. Bot Rev 43 (4): 449-528 https://doi.org/10.1007/BF02860844

48. ALYEMENI MN, SHER H 2010 Impact of human pressure on the population structure of Persicaria amplexicaule, Valeriana jatamansi and Viola serpens the naturally growing medicinal plants in Malam Jaba, Swat, Pakistan. J Med Plant Res 4 (20): 2080-2091

49. BRZOSKO E 2001 Changes in population structure in Carex cespitosa during 10 years of secondary succession in an abandoned meadow in Białowieża, Poland. Ann Bot Fennici 38: 249-258

50. OOSTERMEIJER JGB, VAN 'T VEER R, DEN NIJS JCM 1994 Population structure of the rare, long-lived perennial Gentiana pneumonanthe in relation to vegetation and management in The Netherlands. J Appl Ecol 31: 428-438 https://doi.org/10.2307/2404440

51. KOSTRAKIEWICZ-GIERAŁT K 2013 The effect of vegetation character on abundance and structure of subpopulations of rare herb species Gentiana pneumonanthe L. Pol J Ecol 61 (1): 35-46

52. KOSTRAKIEWICZ-GIERAET K 2016 The variability of Gentiana pneumonanthe L. subpopulations in different habitat conditions. Ecol Questions 23: 51-59 http://dx.doi.org/10.12775/EQ.2016.005

53. SILVERTOWN JW 1987 The introduction to plant population ecology. Longman Scientific \& Technical, London, p. 229.

54. FALIŃSKA K 1997 Life history variation in Cirsium palustre and its consequences for the population demography in vegetation succession. Acta Soc. Bot. Pol. 66 (2): 207-220 https://doi.org/10.5586/asbp.1997.027

55. FORD ED 2014 The dynamic relationship between plant architecture and competition. Front Plant Sci, 5: Article ID 275. https://doi.org/10.3389/fpls.2014.00275

56. RATHER AM, NAWCHOO IA, WANI AA, GANIE AH 2012 Valeriana jatamansi: a phenotypically variable plant species of Kashmir Himalaya. Life Sci J 9 (2): 540-543

57. MUKHERJEE D, CHAKRABORTY S 2014 Studies on ecology, habitats diversification and seed germination behavior of Valeriana jatamansi Jones: A critical endangered plant. Int J Agric Sci 4 (5): 203-209

58. KOTAŃSKA M 1986-1987 Coexistence of populations of Cirsium rivulare (Jacq.) All. and C. oleraceum (L.) Scop. in the Wierzbanówka valley in the Wieliczka Foothills. I. Conditions of occurrence and spatial structure. Fragm Flor Geobot 31-32: 395-421

59. FALIŃSKA K 1995 Genet disintegration in Filipendula ulmaria: Consequences for population dynamics and vegetation succession. J Ecol 83 (10): 9-21 https://doi.org/10.2307/2261146

60. FALIŃSKA K, LEMBICZM, JARMOŁOWSKI A, BORKOWSKA L 2010 Patterns of genetic diversity in populations of Filipendula ulmaria (L.) at different stages of succession on a meadow abandoned for 30 years. Pol J Ecol 58 (1): 27-40.

61. FRANCZAK M, CZARNECKA B 2009 Unitary and iterative growth of clonal species individuals: significance for the spatial structure and the dynamics of population abundance. Ann UMCS, Biologia 64 (2): 9-21 https://doi.org/10.2478/v10067-010-0010-0

62. KOSTRAKIEWICZ-GIERAŁT K 2013 The impact of disturbance gradient on recruitment of clonal plant species in Molinietum caeruleae meadows. Pol J Ecol 519-533.

63. KOSTRAKIEWICZ-GIERAŁT K 2014 Are Deschampsia caespitosa (1.) Beauv. Tussocks safe sites for seedling recruitment in the succession of wet meadows? Pol J Ecol 62: 707-721 https://doi.org/10.3161/104.062.0414 